\title{
Perspectives on Stem Cell Therapy for Cardiac Regeneration
}

\author{
- Advances and Challenges -
}

\author{
Sung Hyun Choi; Seok Yun Jung; Sang-Mo Kwon, PhD; Sang Hong Baek, MD, PhD
}

\begin{abstract}
Ischemic heart disease (IHD) accelerates cardiomyocyte loss, but the developing stem cell research could be useful for regenerating a variety of tissue cells, including cardiomyocytes. Diverse sources of stem cells for IHD have been reported, including embryonic stem cells, induced pluripotent stem cells, skeletal myoblasts, bone marrow-derived stem cells, mesenchymal stem cells, and cardiac stem cells. However, stem cells have unique advantages and disadvantages for cardiac tissue regeneration, which are important considerations in determining the specific cells for improving cell survival and long-term engraftment after transplantation. Additionally, the dosage and administration method of stem cells need to be standardized to increase stability and efficacy for clinical applications. Accordingly, this review presents a summary of the stem cell therapies that have been studied for cardiac regeneration thus far, and discusses the direction of future cardiac regeneration research for stem cells. (Circ J 2012; 76: 13071312)
\end{abstract}

Key Words: Cardiac regeneration; Heart disease; Stem cell therapy

$\mathbf{I}$ schemic heart diseases (IHD), including myocardial infarction (MI), are highly associated with mortality and morbidity in an aging society. ${ }^{1} \mathrm{MI}$ increases the necrosis and cellular apoptosis of cardiomyocytes, placing an excessive load on the heart, which eventually causes heart failure. Progressive loss of cardiomyocytes occurs not only in the ischemic state but also during the heart failure that occurs as a side effect of chronic hypertension. ${ }^{2}$ In contrast, suppressing cardiomyocyte apoptosis in an experimental environment results in improved cardiac function. ${ }^{3}$

Drugs, interventions, and cardiac transplantation as contemporary common treatment methods have shown their limitations for improving the treatment outcomes of patients with heart disease. Thus, some research has been carried out on various methods of overcoming the limits of these current standard treatment methods. In particular, stem cell therapy began to receive attention in the early $2000 \mathrm{~s}$, and active relevant studies have been conducted with the hope of overcoming heart disease. ${ }^{4}$ Cardiomyocytes were known not to proliferate and regenerate in the adult heart, but it is now known that cardiomyocytes can undergo proliferation and division, and that the healing mechanism in mammals (including humans) activates tissues and cell self-regeneration after they are damaged. ${ }^{5}$
However, the ability of human cardiomyocytes to regenerate a damaged heart is insufficient for recovery from a pathological condition.

Accumulating evidence from a wide variety of animal experiments has demonstrated that damaged heart function can be recovered by inducing organ regeneration through the administration of stem cells that have been artificially amplified on a large scale in vitro and have the ability to self-proliferate and differentiate into cardiomyocytes in the damaged area. ${ }^{4}$ However, experimental cardiac regeneration using such stem cells has shown that the effect of the cells on functional heart improvement is rather weak, causing dispute as to whether stem cells differentiate into functional cardiomyocytes. ${ }^{4}$ Therefore, more research must be conducted on stem cell therapy for cardiac regeneration.

This review includes a classification of the stem cell sources that can be used to improve cardiac function and a re-examination of their effect on cardiac regeneration. Furthermore, the direction of future research on stem cell therapy for heart disease is discussed.

Received December 21, 2011; accepted May 8, 2012; released online May 19, 2012

Laboratory of Cardiovascular Regeneration, Division of Cardiovascular Medicine, Seoul St. Mary's Hospital, The Catholic University of Korea School of Medicine, Seoul (S.H.C., S.H.B.); Laboratory of Vascular Medicine and Stem Cell Biology, Department of Physiology, Pusan National University School of Medicine, Yangsan (S.Y.J., S.-M.K.), South Korea

The first two authors contributed equally to this study (S.H.C., S.Y.J.).

Mailing address: Sang Hong Baek, MD, PhD, Division of Cardiovascular Medicine, Seoul St. Mary's Hospital, The Catholic University of Korea School of Medicine, 505, Banpo-dong, Seocho-gu, Seoul, South Korea. E-mail: whitesh@catholic.ac.kr or Sang-Mo Kwon, PhD, Department of Physiology, Pusan National University School of Medicine, Beomero-ri, Mulgeum-eup, Yangsan-si, Gyeongsangnam-do, South Korea. E-mail: smkwon323@hotmail.com

ISSN-1346-9843 doi:10.1253/circj.CJ-11-1479

All rights are reserved to the Japanese Circulation Society. For permissions, please e-mail: cj@j-circ.or.jp 


\section{Mechanisms of Cardiac Regeneration}

Because the heart is a postmitotic organ, cardiomyocytes are in a state of cell cycle arrest. However, some experiments using the newt and zebrafish have confirmed that the damaged heart can be regenerated by resident cardiac cells that had self-regenerating ability. Cardiomyocytes of vertebrates, such as the newt and zebrafish, show low proliferation rates under normal conditions, as in mammals. But, when the heart is damaged, their cardiomyocytes undergo cell division by regulating DNA synthesis and the cell cycle..$^{6,7}$

In contrast, cardiomyocytes' proliferation capability is lost immediately after birth in mammals. Soonpaa et al reported that labeled nuclei are observed in $0.0005 \%$ of cardiomyocytes at baseline and in $0.0083 \%$ of myocytes in the border zone after injury. ${ }^{8}$ In humans, only about $1 \%$ and $0.4 \%$ of cardiomyocytes are renewed each year at the ages of 20 and 75 years, respectively. ${ }^{9}$ In contrast, about $4 \%$ of cardiomyocyte in the border zone are positive for Ki-67 in the hearts of patients who have suffered a MI. ${ }^{10}$ Additionally, mammalian cardiomyocytes undergo remarkable cell division around the border zone of the damaged heart ${ }^{11}$ and overexpression of specific genes promotes division of cardiomyocytes that have been in a state of cell cycle arrest. This observation has amplified the expectation of regenerating damaged cardiomyocytes. ${ }^{12,13}$ These differing findings are a reflection of the lack of standardized analysis methods, although analyses of proliferation-related protein (Ki-67) expression and DNA synthesis are typically used to assess proliferation. Additionally, the number of analyzed cardiomyocytes has also differed.

Despite these controversies, stem cell research for cardiac regeneration has been actively carried out since the $2000 \mathrm{~s}$. Stem cells not only have self-renewal capabilities but also multipotent differentiation abilities and can differentiate into diverse cell types, including cardiomyocytes. In particular, pluripotent stem cells (PSC), such as embryonic stem cells (ESCs) and induced PSC (iPSCs), as well as bone marrow (BM)-derived stem cells (BMSCs), mesenchymal stem cells (MSCs), and resident cardiac stem cells (CSCs), are receiving high recognition as important sources of cell therapeutic agents for cardiac regeneration. ${ }^{14}$ Thus, we will now discuss the features of each of these types of stem cell.

\section{Stem Cell Sources for Cardiac Regeneration} ESCS

ESCs are stem cells derived from the inner cell mass of the blastocyst and have totipotent ability. ESCs are the most advantageous source, as they have the ability to differentiate into various cell types, including cardiomyocytes. ${ }^{15,16}$

ESCs can differentiate into cardiomyocytes under specific culture conditions, such as in cocultures with mouse visceralendoderm-like cells, and various factors essential for cardiac differentiation promote differentiation of ESCs into cardiomyocytes through a paracrine effect. ${ }^{17}$

Xue et al showed that when human ESC-derived cardiac cells are transplanted into an experimental animal model, the ESC-derived cardiac cells are incorporated into the recipient's heart tissue and interact with the recipient heart tissue both electrically and functionally. ${ }^{18}$

Additionally, ESC-derived cardiomyocytes play an important role in regenerating the ischemic area of the heart after treatment for MI, and that also exerts a positive effect on the left ventricle (LV), as judged from a hemodynamic analysis of contraction, regional wall motion, and diastolic dimensions of the expanded LV. ${ }^{19}$ These results suggest that ESCs can differentiate into mature cardiomyocytes, and that ESC-derived cardiomyocytes might functionally couple and interact with host heart tissue. ${ }^{20}$

Despite such studies showing a positive effect of ESCs on cardiac regeneration, only a small proportion of differentiated cardiomyocytes typically have innate contractile ability. ${ }^{16}$ Additionally, the mechanisms by which ESCs differentiate into cardiomyocytes have not been completely demonstrated, although efforts are being made to elucidate the mechanism(s). ${ }^{21}$ Furthermore, ESCs are disadvantageous from the ethical viewpoint. Moreover, injection of ESCs may cause teratoma development or an immune rejection response. For these reasons, no clinical studies have been conducted in which ESCs were used as cell therapy for patients with heart disease.

\section{iPSCs}

In 2007, Yamanaka et al demonstrated PSC, which are similar to ESCs but derived from mature somatic cells using the reverse transcription factors Oct3/4, Sox 2 , Klf4, and c-Myc, and these were named iPSCs. ${ }^{22}$ iPSCs have a pluripotency similar to that of ESCs, and have rapidly emerged as a new source for stem cell therapy that overcomes the ethical problem of ESCs.

iPSCs can differentiate into a variety of cell lineages, including cardiomyocytes. ${ }^{23}$ Nelson et al reported that cell therapy using mouse-derived iPSCs recovers cardiac function in an animal model of IHD. ${ }^{24}$

Although iPSCs have shown positive cardiac regeneration results, they are disadvantageous because the generation yield that can be obtained using the 4 types of genes is extremely low, the efficiency of cardiomyocyte differentiation is poor, and the differentiated cells are a heterogeneous mixture of various types of cells including noncardiomyocytes. ${ }^{25}$ Furthermore, iPSCs have the same problems as ESCs, such as teratoma development and the potential for an immune rejection response after transplantation.

Development of iPSCs is currently at the preclinical research stage, and iPSC generation methods are continuously being developed despite their short history.

\section{Induced Cardiomyocytes and Direct Reprogramming Into Cardiomyocytes}

Interestingly, recently reported studies have demonstrated that cardiomyocyte-like cells can be directly reprogrammed from postnatal cardiac or dermal fibroblasts using 3 cardiac developmental transcription factors: Gata4, Mef2c, and Tbx5 (GMT). ${ }^{26}$ Furthermore, fibroblasts can be directly reprogrammed into cardiomyocytes using exogenously expressed pluripotency genes, such as Oct4, Sox2, and Klf4. ${ }^{27}$ Despite such an amazing result, gene manipulation is still being conducted using viral vectors. Thus, controversy exists about the safety for clinical applications.

The latest results from Srivastava's team are a promising and important step toward cardiac regeneration. After local delivery of GMT-loaded retrovirus in mouse MI model, genetic lineage tracing showed infiltration of myocyte-like cells into the infarct border zone; these cells were confirmed to be descendants of cardiac fibroblasts. In addition, in vivo delivery of GMT decreased the infarct size and modestly attenuated cardiac dysfunction for up to 3 months after coronary ligation. ${ }^{28}$

\section{BMSCs}

BMSCs are the best-characterized cells in terms of surface 
antigens and growth properties in vitro and in vivo. Various studies have reported that treating heart disease with BMSCs has a positive effect on recovery of cardiac function. ${ }^{29-31}$

A recent systematic review showed that the incidence of mortality or morbidity in 33 randomized clinical trials $(1,765$ participants) of patients undergoing BMSC therapy for acute MI was not significantly significant from those undergoing a more standard therapy. Despite the high degree of heterogeneity observed, stem cell treatment improved the left ventricular ejection fraction (LVEF) significantly during a short-term follow-up (weighted mean difference [WMD], 2.87; 95\% confidence interval (CI), 2.00-3.73). This moderate improvement in LVEF was maintained over the long-term follow up of 12-61 months (WMD, 3.75; 95\% CI, 2.57-4.93). ${ }^{32}$

Although some positive reports have indicated that BMSCs could be useful for patients with heart disease, dispute continues concerning their differentiation into cardiomyocytes, because of the lack of definite ground for determining that core cells can exert an effect on cardiac function.

Additionally, BM is not a homogeneous population; its cells have various lineages, including hematopoietic stem cells (HSCs). Some experimental evidence has suggested that diverse isolated HSC populations with $\mathrm{c}-\mathrm{kit}^{+} / \mathrm{Lin}^{-}$and $\mathrm{c}-\mathrm{kit}^{+} /$ Sca- $1^{+} /$Lin $^{-}$improve cardiac function. ${ }^{33,34}$ Furthermore, according to the COMPARE-AMI trial results, CD133+ HSCs also improve LV function after transplantation. ${ }^{35}$ Despite these promising results, debate continues regarding cell differentiation into cardiomyocytes. ${ }^{36,37}$

Endothelial progenitor cells (EPCs), a type of BMSC, are progenitor cells with the ability to differentiate into endothelial cells (ECs). Various studies involving the administration of EPCs have shown positive effects on improving damaged heart function, ${ }^{38,39}$ but the EPCs did not differentiate into cardiomyocytes after transplantation. ${ }^{40}$ However, it was evident that administering EPCs resulted in improved cardiac function. Such an improvement in cardiac function was probably related to the role of EPCs in promoting angiogenesis and supplying sufficient nutrients and oxygen for the survival and division of host cardiomyocytes, as well as replacing novel cardiomyocytes with endogenous stem cells, and also by exerting an additional positive effect on the survival of the replaced cardiomyocytes through a paracrine effect. Nevertheless, the definition of EPCs is still unclear for marker-based isolation, and efforts are necessary to overcome this problem.

\section{MSCs}

MSCs are advantageous because they can be isolated from a variety of tissues, including BM, adipose tissue, and cord blood. MSCs can differentiate into the mesenchymal lineages, including cardiomyocytes, skeletal myoblasts, chondrocytes, and adipose tissue. ${ }^{41-43}$ However, the rate of MSC differentiation into cardiomyocyte in vivo is very low. ${ }^{44}$ After being transplanted into the body, MSCs show a paracrine effect by secreting various cytokines to promote survival, growth, or differentiation of other cells in the area of the MI, and this is considered the major function of MSCs for treatment efficacy. ${ }^{45}$ Moreover, MSCs are immune privileged and have an immunosuppressive function. Because of these special abilities, MSCs can be used as an important source for stem cell-based cell therapy when heterogeneous transplantation is being performed..$^{46}$

However, most of the current studies on adipose-derived MSCs use the mononuclear cell layer, which contains many types of MSCs, rather than using a selected type. Expression of CD166, CD44, CD106, and Stro-1 has generally been used as a marker, but phenotype definitions and cellular characteristics are so diverse that MSCs often show different characteristics depending on their source or donor. Another disadvantage is that the proportion of MSCs that differentiate directly into cardiomyocytes and those that actually survive for a long period is very low, as is the case with other types of stem cells.

\section{Myoblasts}

The first research on cell-based cardiac muscle regeneration that used myoblasts began with transplantation of myoblasts to treat IHD. Myoblasts are present in the basal membrane of the muscle niche and have the ability to regenerate muscle. They show strong resistance against ischemia, and have the ability to differentiate into myotubes in the body. ${ }^{47}$ Thus, myoblasts received immediate recognition as a cell-based therapeutic agent for cardiomyocyte regeneration. Some experiments involving the administration of myoblasts have reported improved LV function. ${ }^{48,49}$

However, despite such positive effects, transplanted myoblasts are unable to transdifferentiate into cardiomyocytes. ${ }^{50}$ Moreover, follow-up results of the MAGIC trial reported that myoblasts transplanted into patients with ischemic cardiomyopathy caused serious side effects, such as arrhythmias. ${ }^{51}$

\section{CSCs}

As already described, cardiomyocyte regeneration using BMSCs and myoblasts has been rather weak. Thus, additional research is necessary. CSCs that can regenerate the heart exist in cardiac tissue, based on previous research, and several groups have identified a population of CSCs in the adult heart.

Stem Cell Antigen (Sca)-1+ Cells Sca-1 is a cell surface antigen used to isolate HSCs. However, some evidence suggests that $\mathrm{Sca}-1^{+}$cells can be isolated from the adult heart, and can transdifferentiate into beating cardiomyocytes when cultured under specific differentiation conditions. ${ }^{52,53}$ Transplanted Sca- $1^{+}$cells home into the infarct border zone, and differentiate into cardiomyocytes, which express cardiac markers such as Nkx2-5 and GATA4. Furthermore, Wang et al reported that transplanting a Sca-1+CD31- CSC population into an animal model improved LV function by angiogenesis. ${ }^{54}$

c-kit+ Cells c-kit ${ }^{+}$cells differentiate into cardiomyocytes, ECs, and smooth muscle cells (SMCs) in vitro, and contribute to regeneration of the myocardium after in vivo transplantation. ${ }^{55}$ According to results from the SCIPIO study, transplantation of c-kit ${ }^{+}$cells improved LV function. ${ }^{56}$ The c-kit ${ }^{+}$cell cardiac marker expression patterns are similar to those of Sca$1^{+}$cells and a minority express Nkx2-5, GATA4, and Mef2c.

Despite these positive results, a study showed a lack of cardiomyocyte regeneration capability of c-kit ${ }^{+}$cells in the adult heart. ${ }^{57}$ Furthermore, the developmental origin of c-kit ${ }^{+}$cells is unclear, because a BM transplantation experiment suggested that many $\mathrm{c}-\mathrm{kit}^{+}$cells in the adult heart are of BM origin. ${ }^{58}$ Furthermore, c-kit is expressed not only in CSCs but also in BM-derived cell populations. ${ }^{31}$

Islet (|s|)-1+ Cells Isl-1 plays an important role in diverse organ development, including the heart. ${ }^{59}$ Isl- $1^{+}$cells also exist in the cardiomyocyte niche, and Laugwitz et al have isolated Isl- $1{ }^{+}$CSCs. ${ }^{60}$ Several studies have suggested that the lack of Isl-1 hampers cardiac developmental potential. ${ }^{61-64}$ Recent studies have suggested that Isl- $1^{+}$cells contribute to all major cell types in the murine heart. ${ }^{59,60,65,66}$ Isolated Isl- $1^{+}$cells proliferate and differentiate into cardiomyocyte, SMC, and EC lineages when they are transplanted. ${ }^{66}$ Isl- $1^{+}$cells are different from Sca- $1^{+}$and c-kit ${ }^{+}$cells because they do not express other stem cell surface markers such as Sca-1 and c-kit.

Cardiac Side Population (SP) Cells Cardiac SP cells have 


\begin{tabular}{|c|c|c|c|c|c|c|}
\hline & ESC & iPSC & BMSC & MSC & MB & $\csc$ \\
\hline \multicolumn{7}{|l|}{ Differentiation capability } \\
\hline Cardiomyocyte & Possible & Possible & Controversial & Possible & Controversial & Possible \\
\hline EC & Possible & Possible & Possible & Possible & No report & Possible \\
\hline SMC & Possible & Possible & Possible & Possible & No report & Possible \\
\hline Other cell types & Possible & Possible & Controversial & Possible & No Report & Controversial \\
\hline Cell source & Limit & Diverse & Limit & Diverse & Limit & Limit \\
\hline Immune rejection response & Exists & Exists & $\begin{array}{l}\text { No exist if } \\
\text { autologous }\end{array}$ & $\begin{array}{l}\text { No exist if } \\
\text { autologous }\end{array}$ & $\begin{array}{l}\text { No exist if } \\
\text { autologous }\end{array}$ & $\begin{array}{l}\text { No exist if } \\
\text { autologous }\end{array}$ \\
\hline $\begin{array}{l}\text { Functionally and electrically synchro- } \\
\text { nized after transplantation }\end{array}$ & Possible & Possible & Impossible & Possible & Impossible & Possible \\
\hline Paracrine effect & Exists & Exists & Exists & Exists & Exists & Exists \\
\hline Isolation markers & Diverse & Diverse & Diverse & Diverse & Diverse & Diverse \\
\hline Isolation purity & Extremely low & Extremely low & Low & Low & Low & Low \\
\hline In vitro amplification capability & Limit & Limit & Limit & Limit & Limit & Limit \\
\hline Teratoma generation & Possible & Possible & No & No & No & No \\
\hline Remarks & $\begin{array}{l}\text { Ethical } \\
\text { problems }\end{array}$ & $\begin{array}{l}\text { Using viral } \\
\text { vectors }\end{array}$ & - & - & - & - \\
\hline
\end{tabular}

ESC, embryonic stem cells; iPSC, induced pluripotent stem cells; BMSC, bone-marrow derived stem cells; MB, myoblasts; CSC, cardiac stem cells; EC, endothelial cells; SMC, smooth muscle cells.

been isolated using the vital dye exclusion method with Hoechst 33342 or Rhodamine 123 , and the cells that extensively effluxed Hoechst 33342 were named SP cells. SP cells have been found in various organs, including BM, skeletal muscle, adipose tissue, ${ }^{67}$ and the heart. ${ }^{68} \mathrm{SP}$ cells express Sca- 1 and can be transdifferentiated into cardiomyocytes to improve LV function. ${ }^{69}$ These stem cells express Nkx2-5, GATA4, and Mef2c after differentiation into cardiomyocytes. SP cells in the heart recover damaged heart function by migrating to the damaged area after the damage has occurred. However, the differentiation mechanism has yet to be elucidated.

Cardiosphere-Derived Cardiac Cells (CDCs) CSC populations have clonogenic ability and form spheroid aggregates in culture (ie, cardiospheres). ${ }^{70} \mathrm{CDCs}$ can differentiate into ECs, SMCs, and cardiomyocytes..$^{71}$ Various studies have suggested that CDCs improve LV function, ${ }^{72,73}$ but they have a disadvantage, in contrast to other stem cells, in that considerable time is required to produce the cardiospheres. Thus, efforts are necessary to overcome this problem. Additionally, CDC-derived cardiac cells are contaminated with other cell types, such as cardiac fibroblasts. This disadvantage could be overcome by using cell surface markers.

Epicardium-Derived Cells (EPDCs) Interestingly, several studies have reported that EDPCs are found in the adult mammalian epicardium. ${ }^{74}$ Limana et al identified that $\mathrm{c}-\mathrm{kit}^{+} / \mathrm{CD} 34^{+} /$ $\mathrm{CD}^{4} 5^{-}$stem cell types exist in the human and the murine epicardium, and that they can be differentiated into cardiomyocyte and vascular lineages. ${ }^{75}$ Furthermore, Wilms tumor $1^{+}$ $\left(\mathrm{Wt}^{+}\right)$cells can also be transdifferentiated into cardiomyocytes. ${ }^{76}$ More recently, Wt1 ${ }^{+}$EPDCs, primed with thymosin $\beta 4$, were transdifferentiated into cardiomyocytes, which functionally incorporated host cardiomyocytes. ${ }^{77}$ However, the differentiation potential of EDPCs is still controversial. Thus, further development is required with cellular surface markers to isolate EDPCs.

As described earlier, CSCs isolated by such diverse methods may have no relationship in terms of differentiation into cardiomyocytes. However, they have the common advantage of being derived from the heart; thus, they could exert a positive effect as a novel cell therapy. ${ }^{78}$ However, CSCs have the disadvantage that they are isolated from biopsy tissue, which may cause functional impairment, particularly for those isolated from older patients because of the aged cells. However, studies are ongoing in many aspects to overcome these problems.

\section{Problems of Cardiac Regeneration Using Stem Cells and Measures to Overcome Limitations}

A variety of stem cell sources can be used to overcome cardiovascular disease, but their advantages and disadvantages have to be clearly distinguished (Table). The primary consideration in the development of stem cell therapeutic agents to overcome cardiovascular diseases should be given to research on methods for improving stem cell survival and long-term engraftment after administration. ${ }^{79}$ Stem cells must be administered in large amounts to show normal function after transplantation, because only an extremely small portion of transplanted stem cells undergo division.

Another consideration is discovering stem cells that have the potential to recover a damaged heart. Although a variety of stem cells have the potential for cardiac regeneration, some researchers have reported that they failed to exert a direct effect on regeneration and functional improvement of the heart. ${ }^{37,50,80}$ Therefore, efforts are needed to develop and analyze specific stem cells for cardiac regeneration.

A third consideration is standardizing the stem cell administration method and dosage. The outcome of treating cardiovascular diseases using stem cells is not so optimistic. The stem cell dosages that have shown positive effects on regenerating damaged heart were all different, and a meta-analysis resulted in very low values with respect to the functional recovery of the LV after stem cell administration. ${ }^{81}$

Last, currently available stem cell administration methods involve injecting through a blood vessel or directly into cardiac muscle, ${ }^{82}$ but the safety of these methods has not been tested. Therefore, an urgent consideration is the establishment of standardized methods to overcome this problem. 


\section{Conclusions}

Based on the results of previous studies, it is clear that various stem cells can exert positive effects on cardiac regeneration. Nevertheless, many barriers must be overcome for these cells to be useful as a therapeutic agent to clinically treat patients. It will be important to develop cell therapeutic agents in which the strong point of each type of stem cell is maximized. However, development of a combined treatment strategy that uses all of the positive aspects of the stem cells, as has been described, would lead to the development of a next-generation stem cell therapeutic agent that has more positive effects on cardiovascular disease.

\section{Acknowledgments}

This work was supported by a grant from the Korea Healthcare Technology R \& D Project, Ministry of Health, Welfare, and Family Affairs, Republic of Korea (A100638), and this work was also supported by a National Research Foundation grant funded by the Korean government (2010-0020260)

\section{References}

1. Lopez AD, Mathers CD, Ezzati M, Jamison DT, Murray CJ. Global and regional burden of disease and risk factors, 2001: Systematic analysis of population health data. Lancet 2006; 367: 1747-1757.

2. Diwan A, Dorn GW 2nd. Decompensation of cardiac hypertrophy: Cellular mechanisms and novel therapeutic targets. Physiology (Bethesda) 2007; 22: 56-64.

3. Diwan A, Krenz M, Syed FM, Wansapura J, Ren X, Koesters AG, et al. Inhibition of ischemic cardiomyocyte apoptosis through targeted ablation of bnip3 restrains postinfarction remodeling in mice. J Clin Invest 2007; 117: 2825-2833.

4. Abdel-Latif A, Bolli R, Tleyjeh IM, Montori VM, Perin EC, Hornung $\mathrm{CA}$, et al. Adult bone marrow-derived cells for cardiac repair: A systematic review and meta-analysis. Arch Intern Med 2007; 167: 989-997.

5. Leri A, Kajstura J, Anversa P. Cardiac stem cells and mechanisms of myocardial regeneration. Physiol Rev 2005; 85: 1373-1416.

6. Borchardt T, Braun T. Cardiovascular regeneration in non-mammalian model systems: What are the differences between newts and man? Thromb Haemost 2007; 98: 311-318.

7. Poss KD. Getting to the heart of regeneration in zebrafish. Semin Cell Dev Biol 2007; 18: 36-45.

8. Soonpaa MH, Field LJ. Assessment of cardiomyocyte DNA synthesis in normal and injured adult mouse hearts. Am J Physiol 1997; 272: $\mathrm{H} 220-\mathrm{H} 226$.

9. Bergmann O, Bhardwaj RD, Bernard S, Zdunek S, Barnabe-Heider F, Walsh S, et al. Evidence for cardiomyocyte renewal in humans. Science 2009; 324: $98-102$.

10. Beltrami AP, Urbanek K, Kajstura J, Yan SM, Finato N, Bussani R, et al. Evidence that human cardiac myocytes divide after myocardial infarction. N Engl J Med 2001; 344: 1750-1757.

11. Ahuja P, Sdek P, MacLellan WR. Cardiac myocyte cell cycle control in development, disease, and regeneration. Physiol Rev 2007; 87: $521-544$.

12. Hosoda T, Kajstura J, Leri A, Anversa P. Mechanisms of myocardial regeneration. Circ J 2010; 74: 13-17.

13. Rubart M, Field LJ. Cardiac regeneration: Repopulating the heart. Апnи Rev Physiol 2006; 68: 29-49.

14. Roccio M, Goumans MJ, Sluijter JP, Doevendans PA. Stem cell sources for cardiac regeneration. Panminerva Med 2008; 50: 19-30.

15. Keller G. Embryonic stem cell differentiation: Emergence of a new era in biology and medicine. Genes Dev 2005; 19: 1129-1155.

16. Mignone JL, Kreutziger KL, Paige SL, Murry CE. Cardiogenesis from human embryonic stem cells. Circ J 2010; 74: 2517-2526.

17. Mummery C, Ward-van Oostwaard D, Doevendans P, Spijker R, van den Brink S, Hassink R, et al. Differentiation of human embryonic stem cells to cardiomyocytes: Role of coculture with visceral endoderm-like cells. Circulation 2003; 107: 2733-2740.

18. Xue T, Cho HC, Akar FG, Tsang SY, Jones SP, Marban E, et al. Functional integration of electrically active cardiac derivatives from genetically engineered human embryonic stem cells with quiescent recipient ventricular cardiomyocytes: Insights into the development of cell-based pacemakers. Circulation 2005; 111: 11-20.

19. Caspi O, Huber I, Kehat I, Habib M, Arbel G, Gepstein A, et al.
Transplantation of human embryonic stem cell-derived cardiomyocytes improves myocardial performance in infarcted rat hearts. $J \mathrm{Am}$ Coll Cardiol 2007; 50: 1884-1893.

20. Nakamura T, Schneider MD. The way to a human's heart is through the stomach: Visceral endoderm-like cells drive human embryonic stem cells to a cardiac fate. Circulation 2003; 107: 2638-2639.

21. Condorelli G, Catalucci D. Human stem cells for heart failure treatment ready for prime time? J Am Coll Cardiol 2007; 50: 18941895.

22. Takahashi K, Yamanaka S. Induction of pluripotent stem cells from mouse embryonic and adult fibroblast cultures by defined factors. Cell 2006; 126: 663-676.

23. Zhang J, Wilson GF, Soerens AG, Koonce CH, Yu J, Palecek SP, et al. Functional cardiomyocytes derived from human induced pluripotent stem cells. Circ Res 2009; 104: e30-e41.

24. Nelson TJ, Martinez-Fernandez A, Yamada S, Perez-Terzic C, Ikeda Y, Terzic A. Repair of acute myocardial infarction by human stemness factors induced pluripotent stem cells. Circulation 2009; 120: $408-416$.

25. Yoshida Y, Yamanaka S. IPS cells: A source of cardiac regeneration. J Mol Cell Cardiol 2011; 50: 327-332.

26. Ieda M, Fu JD, Delgado-Olguin P, Vedantham V, Hayashi Y, Bruneau $\mathrm{BG}$, et al. Direct reprogramming of fibroblasts into functional cardiomyocytes by defined factors. Cell 2010; 142: 375-386.

27. Efe JA, Hilcove S, Kim J, Zhou H, Ouyang K, Wang G, et al. Conversion of mouse fibroblasts into cardiomyocytes using a direct reprogramming strategy. Nat Cell Biol 2011; 13: 215-222.

28. Qian L, Huang Y, Spencer CI, Foley A, Vedantham V, Liu L, et al. In vivo reprogramming of murine cardiac fibroblasts into induced cardiomyocytes. Nature 2012 [Epub ahead of print].

29. Orlic D, Kajstura J, Chimenti S, Limana F, Jakoniuk I, Quaini F, et al. Mobilized bone marrow cells repair the infarcted heart, improving function and survival. Proc Natl Acad Sci USA 2001; 98: 1034410349.

30. Yoon YS, Wecker A, Heyd L, Park JS, Tkebuchava T, Kusano K, et al. Clonally expanded novel multipotent stem cells from human bone marrow regenerate myocardium after myocardial infarction. J Clin Invest 2005; 115: 326-338.

31. Kajstura J, Rota M, Whang B, Cascapera S, Hosoda T, Bearzi C, et al. Bone marrow cells differentiate in cardiac cell lineages after infarction independently of cell fusion. Circ Res 2005; 96: 127-137.

32. Clifford DM, Fisher SA, Brunskill SJ, Doree C, Mathur A, Watt S, et al. Stem cell treatment for acute myocardial infarction. Cochrane Database Syst Rev 2012; 2: CD006536.

33. Orlic D, Kajstura J, Chimenti S, Jakoniuk I, Anderson SM, Li B, et al. Bone marrow cells regenerate infarcted myocardium. Nature 2001; 410: $701-705$.

34. Templin C, Kotlarz D, Faulhaber J, Schnabel S, Grote K, Salguero G, et al. Ex vivo expanded hematopoietic progenitor cells improve cardiac function after myocardial infarction: Role of beta-catenin transduction and cell dose. J Mol Cell Cardiol 2008; 45: 394-403.

35. Mansour S, Roy DC, Bouchard V, Nguyen BK, Stevens LM, Gobeil F, et al. COMPARE-AMI trial: Comparison of intracoronary injection of CD133+ bone marrow stem cells to placebo in patients after acute myocardial infarction and left ventricular dysfunction: Study rationale and design. J Cardiovasc Transl Res 2010; 3: 153-159.

36. Balsam LB, Wagers AJ, Christensen JL, Kofidis T, Weissman IL, Robbins RC. Haematopoietic stem cells adopt mature haematopoietic fates in ischaemic myocardium. Nature 2004; 428: 668-673.

37. Murry CE, Soonpaa MH, Reinecke H, Nakajima H, Nakajima HO, Rubart M, et al. Haematopoietic stem cells do not transdifferentiate into cardiac myocytes in myocardial infarcts. Nature 2004; 428: $664-668$.

38. Jujo K, Ii M, Losordo DW. Endothelial progenitor cells in neovascularization of infarcted myocardium. J Mol Cell Cardiol 2008; 45: $530-544$.

39. Leone AM, Rutella S, Giannico MB, Perfetti M, Zaccone V, Brugaletta $\mathrm{S}$, et al. Effect of intensive vs standard statin therapy on endothelial progenitor cells and left ventricular function in patients with acute myocardial infarction: Statins for Regeneration after Acute myocardial infarction and PCI (STRAP) trial. Int J Cardiol 2008; 130: 457 462.

40. Gruh I, Beilner J, Blomer U, Schmiedl A, Schmidt-Richter I, Kruse ML, et al. No evidence of transdifferentiation of human endothelial progenitor cells into cardiomyocytes after coculture with neonatal rat cardiomyocytes. Circulation 2006; 113: 1326-1334.

41. Barry FP, Murphy JM. Mesenchymal stem cells: Clinical applications and biological characterization. Int J Biochem Cell Biol 2004; 36: $568-584$.

42. Xu X, Xu Z, Xu Y, Cui G. Selective down-regulation of extracellular 
matrix gene expression by bone marrow derived stem cell transplantation into infarcted myocardium. Circ J 2005; 69: 1275-1283.

43. Xu H, Yang YJ, Qian HY, Tang YD, Wang H, Zhang Q. Rosuvastatin treatment activates JAK-STAT pathway and increases efficacy of allogeneic mesenchymal stem cell transplantation in infarcted hearts. Circ J 2011; 75: 1476-1485.

44. Amado LC, Saliaris AP, Schuleri KH, St John M, Xie JS, Cattaneo S, et al. Cardiac repair with intramyocardial injection of allogeneic mesenchymal stem cells after myocardial infarction. Proc Natl Acad Sci USA 2005; 102: 11474-11479.

45. Caplan AI, Dennis JE. Mesenchymal stem cells as trophic mediators. J Cell Biochem 2006; 98: 1076-1084.

46. Aggarwal S, Pittenger MF. Human mesenchymal stem cells modulate allogeneic immune cell responses. Blood 2005; 105: 1815-1822.

47. Menasche P. Skeletal myoblasts as a therapeutic agent. Prog Cardiovasc Dis 2007; 50: 7-17.

48. Pagani FD, DerSimonian H, Zawadzka A, Wetzel K, Edge AS, Jacoby DB, et al. Autologous skeletal myoblasts transplanted to ischemiadamaged myocardium in humans: Histological analysis of cell survival and differentiation. J Am Coll Cardiol 2003; 41: 879-888.

49. Ghostine S, Carrion C, Souza LC, Richard P, Bruneval P, Vilquin JT, et al. Long-term efficacy of myoblast transplantation on regional structure and function after myocardial infarction. Circulation 2002; 106: I131-I136.

50. Reinecke H, Poppa V, Murry CE. Skeletal muscle stem cells do not transdifferentiate into cardiomyocytes after cardiac grafting. $J \mathrm{Mol}$ Cell Cardiol 2002; 34: 241-249.

51. Eisen HJ. Skeletal myoblast transplantation: No magic bullet for ischemic cardiomyopathy. Nat Clin Pract Cardiovasc Med 2008; 5: $520-521$.

52. Oh H, Bradfute SB, Gallardo TD, Nakamura T, Gaussin V, Mishina $\mathrm{Y}$, et al. Cardiac progenitor cells from adult myocardium: Homing, differentiation, and fusion after infarction. Proc Natl Acad Sci USA 2003; 100: 12313-12318.

53. Matsuura K, Nagai T, Nishigaki N, Oyama T, Nishi J, Wada H, et al. Adult cardiac Sca-1-positive cells differentiate into beating cardiomyocytes. J Biol Chem 2004; 279: 11384-11391.

54. Wang X, Hu Q, Nakamura Y, Lee J, Zhang G, From AH, et al. The role of the $\mathrm{Sca}-1^{+} / \mathrm{CD} 31^{-}$cardiac progenitor cell population in postinfarction left ventricular remodeling. Stem Cells 2006; 24: 1779 1788 .

55. Beltrami AP, Barlucchi L, Torella D, Baker M, Limana F, Chimenti $\mathrm{S}$, et al. Adult cardiac stem cells are multipotent and support myocardial regeneration. Cell 2003; 114: 763-776.

56. Bolli R, Chugh AR, D'Amario D, Loughran JH, Stoddard MF, Ikram $\mathrm{S}$, et al. Cardiac stem cells in patients with ischaemic cardiomyopathy (SCIPIO): Initial results of a randomised phase 1 trial. Lancet 2011; 378: $1847-1857$

57. Zaruba MM, Soonpaa M, Reuter S, Field LJ. Cardiomyogenic potential of c-kit(+)-expressing cells derived from neonatal and adult mouse hearts. Circulation 2010; 121: 1992-2000.

58. Fazel S, Cimini M, Chen L, Li S, Angoulvant D, Fedak P, et al. Cardioprotective c-kit+ cells are from the bone marrow and regulate the myocardial balance of angiogenic cytokines. J Clin Invest 2006; 116: $1865-1877$.

59. Cai CL, Liang X, Shi Y, Chu PH, Pfaff SL, Chen J, et al. Isl1 identifies a cardiac progenitor population that proliferates prior to differentiation and contributes a majority of cells to the heart. Dev Cell 2003; 5: 877-889.

60. Laugwitz KL, Moretti A, Lam J, Gruber P, Chen Y, Woodard S, et al. Postnatal Is $11^{+}$cardioblasts enter fully differentiated cardiomyocyte lineages. Nature 2005; 433: 647-653.

61. Chien KR, Domian IJ, Parker KK. Cardiogenesis and the complex biology of regenerative cardiovascular medicine. Science 2008; 322: $1494-1497$

62. Laugwitz KL, Moretti A, Caron L, Nakano A, Chien KR. Islet1 car- diovascular progenitors: A single source for heart lineages? Development 2008; 135: 193-205.

63. Martin-Puig S, Wang Z, Chien KR. Lives of a heart cell: Tracing the origins of cardiac progenitors. Cell Stem Cell 2008; 2: 320-331.

64. Wu SM, Chien KR, Mummery C. Origins and fates of cardiovascular progenitor cells. Cell 2008; 132: 537-543.

65. Kattman SJ, Huber TL, Keller GM. Multipotent flk-1+ cardiovascular progenitor cells give rise to the cardiomyocyte, endothelial, and vascular smooth muscle lineages. Dev Cell 2006; 11: 723-732.

66. Moretti A, Caron L, Nakano A, Lam JT, Bernshausen A, Chen Y, et al. Multipotent embryonic Isl1 $1^{+}$progenitor cells lead to cardiac, smooth muscle, and endothelial cell diversification. Cell 2006; 127: $1151-1165$.

67. Challen GA, Little MH. A side order of stem cells: The SP phenotype. Stem Cells 2006; 24: 3-12.

68. Martin CM, Meeson AP, Robertson SM, Hawke TJ, Richardson JA, Bates S, et al. Persistent expression of the ATP-binding cassette transporter, abcg2, identifies cardiac SP cells in the developing and adult heart. Dev Biol 2004; 265: 262-275.

69. Oyama T, Nagai T, Wada H, Naito AT, Matsuura K, Iwanaga K, et al. Cardiac side population cells have a potential to migrate and differentiate into cardiomyocytes in vitro and in vivo. J Cell Biol 2007; 176: $329-341$

70. Messina E, De Angelis L, Frati G, Morrone S, Chimenti S, Fiordaliso $\mathrm{F}$, et al. Isolation and expansion of adult cardiac stem cells from human and murine heart. Circ Res 2004; 95: 911-921.

71. Takehara N, Tsutsumi Y, Tateishi K, Ogata T, Tanaka H, Ueyama T, et al. Controlled delivery of basic fibroblast growth factor promotes human cardiosphere-derived cell engraftment to enhance cardiac repair for chronic myocardial infarction. J Am Coll Cardiol 2008; 52: $1858-1865$.

72. Dawn B, Stein AB, Urbanek K, Rota M, Whang B, Rastaldo R, et al. Cardiac stem cells delivered intravascularly traverse the vessel barrier, regenerate infarcted myocardium, and improve cardiac function. Proc Natl Acad Sci USA 2005; 102: 3766-3771.

73. Smith RR, Barile L, Cho HC, Leppo MK, Hare JM, Messina E, et al. Regenerative potential of cardiosphere-derived cells expanded from percutaneous endomyocardial biopsy specimens. Circulation 2007; 115: 896-908.

74. Smart N, Risebro CA, Melville AA, Moses K, Schwartz RJ, Chien $\mathrm{KR}$, et al. Thymosin beta4 induces adult epicardial progenitor mobilization and neovascularization. Nature 2007; 445: 177-182.

75. Limana F, Zacheo A, Mocini D, Mangoni A, Borsellino G, Diamantini A, et al. Identification of myocardial and vascular precursor cells in human and mouse epicardium. Circ Res 2007; 101: 1255-1265.

76. Zhou B, Ma Q, Rajagopal S, Wu SM, Domian I, Rivera-Feliciano J, et al. Epicardial progenitors contribute to the cardiomyocyte lineage in the developing heart. Nature 2008; 454: 109-113.

77. Smart N, Bollini S, Dube KN, Vieira JM, Zhou B, Davidson S, et al. De novo cardiomyocytes from within the activated adult heart after injury. Nature 2011; 474: 640-644.

78. Tang XL, Rokosh DG, Guo Y, Bolli R. Cardiac progenitor cells and bone marrow-derived very small embryonic-like stem cells for cardiac repair after myocardial infarction. Circ J 2010; 74: 390-404.

79. Zhang G, Hu Q, Braunlin EA, Suggs LJ, Zhang J. Enhancing efficacy of stem cell transplantation to the heart with a pegylated fibrin biomatrix. Tissue Eng Part A 2008; 14: 1025-1036.

80. Stuckey DJ, Carr CA, Martin-Rendon E, Tyler DJ, Willmott C, Cassidy $\mathrm{PJ}$, et al. Iron particles for noninvasive monitoring of bone marrow stromal cell engraftment into, and isolation of viable engrafted donor cells from, the heart. Stem Cells 2006; 24: 1968-1975.

81. Chamuleau SA, Vrijsen KR, Rokosh DG, Tang XL, Piek JJ, Bolli R. Cell therapy for ischaemic heart disease: Focus on the role of resident cardiac stem cells. Neth Heart J 2009; 17: 199-207.

82. Mozid AM, Arnous S, Sammut EC, Mathur A. Stem cell therapy for heart diseases. Br Med Bull 2011; 98: 143-159. 